\title{
EXPERIMENTAL INFECTION OF SHEEP WITH STRAINS OF RIFT VALLEY FEVER VIRUS
}

\author{
El-Nahas, E.M. \\ Departments of virology, Faculty of Veterinary Medicine, \\ Moshtohor, Benha University, Egypt.
}

\begin{abstract}
Nine, 5 month old baladi sheep were divided into 3 groups, group I was inoculated with Rift Valley Fever (RVF) virus ZH501strain, group $\Pi$ was inoculated with RVF virus Smithburn strain, and group III was non inoculated kept as control. The rectal temperature was recorded and a trial for virus isolation and identification besides following up the antibody response using indirect solid phase ELISA (SPE) were adopted. Group I showed fever continued for 5 to 6 day post inoculation (d.p.i) and successful virus isolation from eye at $3^{\text {rd }}$ and $7^{\text {th }}$ d.p.i, from nose at $3^{\text {rd }}$ d.p.i from rectum at $3^{\text {rd }}$, and $9^{\text {th }}$ d.p.i, whereas plasma and Buffy coat were found to be positive till $5^{\text {th }}$ d.p.i and sera till $11^{\text {th }}$ d.p.i, meanwhile the antibody response increased from the $6^{\text {th }}$ and $7^{\text {th }}$ d.p.i till the end of experiment. Group $\Pi$ revealed increase body temperature at $3^{\text {rd }}$ and $4^{\text {th }}$ d.p.i and RVF virus disappeared from eye, nose, and rectum, but successful virus isolation from blood continued until the $3^{\text {rd }}$ and $4^{\text {th }}$ d.p.i, moreover the antibody response appear at the $4^{\text {th }}$ and $5^{\text {th }}$ d.p.i and continued to increase with higher values than group I till the end of experiment. Group III exposed normal body temperature without virus shedding or antibodies in their sera. In conclusion Smithburn strain can be used as attenuated vaccine or a seed for production of inactivated vaccine as it was more immunogenic than ZH501 strain.
\end{abstract}




\section{INTRODUCTION}

Rift Valley fever (RVF) virus, a Phlebovirus from the family Bunyaviridae, which is potentially transmitted by many different species of insect vectors that have a wide global distribution (Gubler, 2002). Periodic RVF outbreaks in livestock (goats, sheep, cattle, and camels) and acute febrile illness with hemorrhagic syndrome in humans have been reported widely throughout south and central Africa, from Kenya westward into Nigeria, Niger, Burkina Faso, Senegal, and Mauritania and northward into Egypt (Diallo et al., 2005). The serological methods that have been used earlier for the diagnosis of RVF have now been largely replaced by enzyme linked immunosorbent assay (ELISA) systems that detect $\operatorname{IgM}$ and/or IgG antibodies directed against RVF virus proteins (Flick and Bouloy, 2005). Several animal models of RVF virus infection have been described These may be useful in understanding the nature of key pathogenetic processes applicable to human infections or for the development and testing of vaccines and therapeutic agents. As such, they have the potential to satisfy key provisions of the Food and Drug Administration's (FDA) 'Animal Rule,' which allows for the demonstration of drug or vaccine efficacy using animal studies instead of human clinical trials (Snoy, 2010). In our search we used a sheep as a natural animal model to study the pathogenic and immunogenic effect of both ZH501 and Smithburn strains of RVF virus. 


\section{MATERIALS AND METHODS}

\subsection{RVF virus strains:}

2.1.1. Zagazig Human 501 (ZH501): It was passaged twice intracerebrally into suckling mice and twice in BHK-21. The titer was $10^{7} \mathrm{TCID}_{50} / \mathrm{ml}$ on BHK-21.

2.1.2. Smithburn neurotropic strain at $104^{\text {th }}$ mouse brain passage followed by 2 passages in BHK-21. The titer was $10^{8} \mathrm{TCID}_{50} / \mathrm{ml}$ on BHK-21.

Both strains were supplied by RVF Department, Veterinary Serum and Vaccine Research Institute, Abbasia, Cairo and used in experimental infection of sheep .

2.3. Baby Hamster Kidney (BHK-21) cell line: It was supplied by RVF Department, Veterinary Serum and Vaccine Research Institute, Abbasia, Cairo. The cells were grown and maintained according to Macpherson and Stocker (1962). It was used for virus isolation and serum neutralization test (SNT).

2.4. Sheep: Nine, 5 months old baladi sheep were allotted into 3 groups ( 3 sheep for each group) and kept in separate breeding rooms. The sera from these sheep were perviously screened by SNT for the presence of specific antibodies against RVF virus and did not reveal any specific antibodies (sero-negative). They were used through the experimental design. 
2.5. Serum samples: All sera were collected from three groups on the day of inoculation (zero day) till 21 day post-inoculation, were examined for antibody response to both ZH501 and Smithburn strains of RVF virus by solid phase ELISA.

\subsection{Biological reagents:}

2.6.1. Lyophilized RVF virus Cell lysate Antigen (LCA): It was supplied by RVF Department, Veterinary Serum and Vaccine Research Institute, Abbasia, Cairo and used as coating antigen in solid phase Elisa.

2.6.2. Sheep anti-RVF hyperimmune serum: It was supplied by RVF Department, Veterinary Serum and Vaccine Research Institute, Abbasia, Cairo and used in SNT.

2.6.3. Conjugate: rabbit antisheep $\operatorname{IgG}$ conjugated with horse reddish peroxidase supplied by Sigma. It was used in solid phase ELISA.

2.7. Virus isolation and identification: Serum samples, heparinized blood as well as ocular, nasal and fecal swabs were collected from each animal of the 3 groups starting from the day of inoculation (zero day) till 21 day post-inoculation. They were tested for virus shedding using BHK cell culture inoculation and SNT

2.8. Serum neutralization test (SNT): It was carried out according to flourence (1992) for RVF virus identification and to screen the sera of sheep before experimental infection. 
2.9. Indirect solid phase ELISA: It was carried out as described by Voller et al., (1976) to detect antibody response in sera of inoculated sheep.

2.10. Experimental design: The sheep were divided in three groups as follow:

Group I: Each of three sheep was inoculated subcutaenously with $1 \mathrm{ml}$ (100.000 virus particles) of ZH501 RVF virus strain.

Group П: Each of three sheep was inoculated sub-cutaenously with $1 \mathrm{ml}$ (100.000 virus particles) of Smithburn RVF virus strain.

Group III: control negative group.

Sheep were housed in mosquito proof isolated stable and daily observed as well as body tempreature was recorded.

\section{RESULTS}

3.1. Thermal reaction and clinical signs of sheep following experimental infection with ZH501 or Smithburn strains: In group I "sheep inoculated with ZH501 RVF virus strain" showed fever that raised from the first day of inoculation and persisted for the $5^{\text {th }}$ and $6^{\text {th }}$ day of inoculation that lead to loss of appetite, dullness, congestion of mucous membranes, lacrimation and congestion of third eye lid, mucopurulent nasal discharges and diarrhea. While in group $\Pi$ "sheep inoculated with Smithburn RVF virus strain" no clinical signs appear except increase in body temperature at $3^{\text {rd }}$ and $4^{\text {th }}$ day of inoculation, then return to normal level as revealed in table (1). 
Table (1): rectal body temperature of sheep following infection either with ZH501 or Smithburn RVFV strains.

\begin{tabular}{|c|c|c|c|c|c|c|c|c|c|}
\hline \multirow{2}{*}{$\begin{array}{c}\text { Days } \\
\text { P.I }\end{array}$} & \multicolumn{3}{|c|}{ Group I } & \multicolumn{3}{|c|}{ Group II } & \multicolumn{3}{|c|}{ Group III (control) } \\
\hline & ${ }^{*}$ Sh1 & Sh2 & Sh3 & Sh4 & Sh5 & Sh6 & Sh7 & Sh8 & Sh9 \\
\hline 1 & 39.9 & 41.0 & 39.9 & 39.0 & 39.1 & 38.9 & 39.0 & 39.1 & 39.0 \\
\hline 2 & 40.0 & 42.0 & 39.8 & 39.1 & 39.0 & 39.4 & 39.1 & 39.0 & 39.1 \\
\hline 3 & 41.1 & 41.0 & 40.9 & 39.9 & 40.1 & 39.0 & 39.2 & 39.1 & 39.2 \\
\hline 4 & 40.0 & 42.0 & 40.5 & 40.2 & 41.0 & 39.2 & 39.0 & 39.0 & 39.0 \\
\hline 5 & 39.9 & 40.0 & 41.0 & 39.4 & 39.1 & 38.9 & 39.0 & 39.0 & 39.0 \\
\hline 6 & 38.9 & 39.8 & 39.9 & 39.3 & 39.0 & 39.0 & 39.0 & 39.0 & 39.0 \\
\hline 7 & 39.0 & 39.5 & 39.7 & 39.2 & 39.0 & 39.0 & 39.0 & 39.0 & 39.0 \\
\hline 8 & 39.0 & 39.4 & 39.5 & 39.0 & 39.1 & 39.1 & 39.3 & 39.3 & 39.3 \\
\hline 9 & 39.1 & 39.3 & 39.5 & 39.0 & 39.2 & 39.2 & 39.2 & 39.2 & 39.2 \\
\hline 10 & 39.2 & 39.1 & 39.3 & 39.1 & 39.1 & 39.3 & 39.1 & 39.1 & 39.1 \\
\hline 11 & 39.1 & 39.2 & 39.2 & 39.2 & 39.3 & 39.0 & 39.0 & 39.0 & 39.0 \\
\hline 12 & 39.3 & 39.1 & 39.0 & 39.0 & 39.0 & 39.1 & 38.9 & 38.9 & 38.9 \\
\hline 13 & 39.0 & 39.0 & 39.1 & 38.9 & 38.9 & 39.0 & 38.9 & 38.9 & 38.9 \\
\hline 14 & 39.1 & 39.0 & 39.2 & 38.9 & 38.9 & 39.2 & 39.1 & 39.1 & 39.1 \\
\hline 15 & 39.1 & 39.1 & 38.9 & 39.0 & 39.0 & 39.1 & 39.0 & 39.0 & 39.0 \\
\hline 16 & 38.9 & 38.9 & 39.1 & 39.1 & 39.0 & 39.0 & 39.1 & 39.1 & 39.1 \\
\hline 17 & 39.2 & 39.1 & 39.0 & 39.0 & 39.0 & 39.0 & 39.1 & 39.0 & 39.1 \\
\hline 18 & 39.1 & 39.0 & 39.0 & 39.1 & 38.9 & 39.2 & 39.0 & 39.0 & 39.0 \\
\hline 19 & 39.3 & 39.2 & 39.1 & 38.9 & 39.0 & 39.1 & 39.1 & 39.1 & 39.1 \\
\hline 20 & 38.9 & 39.0 & 39.2 & 39.0 & 39.0 & 39.0 & 39.2 & 39.1 & 39.2 \\
\hline 21 & 39.0 & 39.1 & 39.0 & 39.0 & 39.1 & 39.0 & 39.1 & 39.1 & 39.1 \\
\hline
\end{tabular}

* sheep number

P.I=post inoculation

3.2. Virus isolation and identification: Successful virus isolation and identification started from $1^{\text {st }}$ and $2^{\text {nd }}$ day post inoculation till 10th and 11th d.p.i mainly from serum, plasma and buffy coat and occasionally from nasal, eye and rectal swabs in group I. While in group $\Pi$ only positive virus isolation and identification from plasma were detected at 2nd d.p.i, then from plasma and serum at 3rd d.p.i. and presence of virus in serum till 4th and 5th d.p.i. as observed in figure (1) and table (2). 


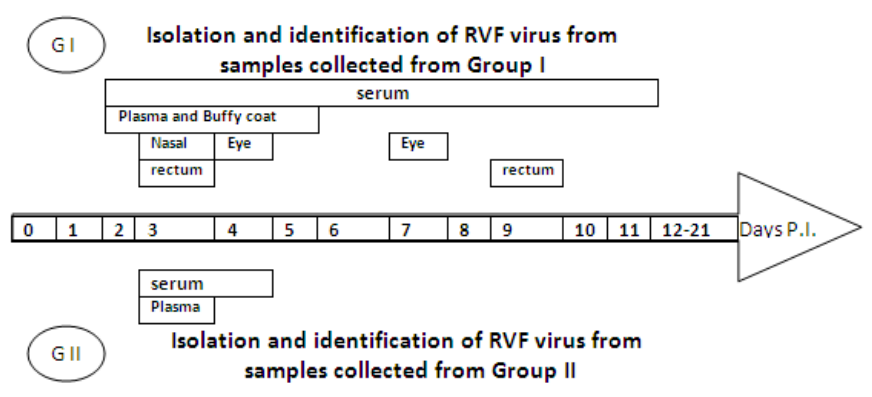

Figure (1): isolation of RVF virus from body fluid and discharges of sheep following infection with either with ZH501 (group 1) or Smithburn strains (group II).

Table (2): Isolation and identification of RVF virus from samples collected from sheep following infection either with ZH501 (group 1) or Smithburn strains (group II).

\begin{tabular}{|c|c|c|c|c|c|c|c|c|c|}
\hline \multirow{2}{*}{$\begin{array}{c}\text { Days } \\
\text { P.I }\end{array}$} & \multicolumn{3}{|c|}{ Group I } & \multicolumn{3}{|c|}{ Group II } & \multicolumn{3}{|c|}{ "Group III (control) } \\
\hline & "*Sh1 & Sh2 & Sh3 & Sh4 & Sh5 & Sh6 & Sh7 & Sh8 & Sh9 \\
\hline 1 & 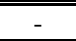 & 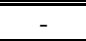 & s & 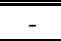 & - & 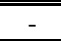 & - & 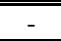 & 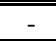 \\
\hline 2 & $\mathrm{~s} / \mathrm{p} / \mathrm{b}$ & $\mathrm{s} / \mathrm{p} / \mathrm{b}$ & $\mathrm{s}$ & $\mathrm{p}$ & - & $\mathrm{p}$ & - & - & - \\
\hline 3 & $\mathrm{~s} / \mathrm{p} / \mathrm{b}$ & $\mathrm{s} / \mathrm{p} / \mathrm{b} / \mathrm{n}$ & $\mathrm{s} / \mathrm{p} / \mathrm{b} / \mathrm{r}$ & $\mathrm{p} / \mathrm{s}$ & $\mathrm{s}$ & $\mathrm{s}$ & - & - & - \\
\hline 4 & $\mathrm{~s} / \mathrm{p} / \mathrm{b}$ & $\mathrm{s} / \mathrm{p} / \mathrm{b}$ & $\mathrm{s} / \mathrm{p} / \mathrm{b} / \mathrm{e}$ & $\mathrm{s}$ & - & $\mathrm{s}$ & - & - & - \\
\hline 5 & $\mathrm{~s} / \mathrm{p} / \mathrm{b}$ & $\mathrm{s} / \mathrm{p} / \mathrm{b}$ & $\mathrm{s}$ & - & - & - & - & - & - \\
\hline 6 & $\mathrm{~s}$ & $\mathrm{~s}$ & $\mathrm{~s}$ & - & - & - & - & - & - \\
\hline 7 & $\mathrm{~s}$ & $\mathrm{~s} / \mathrm{e}$ & $\mathrm{s}$ & - & - & - & - & - & - \\
\hline 8 & $\mathrm{~s}$ & $\mathrm{~s}$ & $\mathrm{~s}$ & - & - & - & - & - & - \\
\hline 9 & $\mathrm{~s}$ & $\mathrm{~s}$ & $\mathrm{~s} / \mathrm{r}$ & - & - & - & - & - & - \\
\hline 10 & $\mathrm{~s}$ & $\mathrm{~s}$ & $\mathrm{~s}$ & - & - & - & - & - & - \\
\hline 11 & $\mathrm{~s}$ & $\mathrm{~s}$ & - & - & - & - & - & - & - \\
\hline 12 & - & - & - & - & - & - & - & - & - \\
\hline 13 & - & - & - & - & - & - & - & - & - \\
\hline 14 & - & - & - & - & - & - & - & - & - \\
\hline 15 & - & - & - & - & - & - & - & - & - \\
\hline 16 & - & - & - & - & - & - & - & - & - \\
\hline 17 & - & - & - & - & - & - & - & - & - \\
\hline 18 & - & - & - & - & - & - & - & - & - \\
\hline 19 & - & - & - & - & - & - & - & - & - \\
\hline 20 & - & - & - & - & - & - & - & - & - \\
\hline 21 & - & - & - & - & - & - & - & - & - \\
\hline
\end{tabular}

Positive RVF virus isolation and identification was from $\mathrm{s}=$ serum, $\mathrm{p}=$ plasma, $\mathrm{b}=$ buffy coat, $\mathrm{r}=$ rectal swab, $\mathrm{n}=\mathrm{nasal}$ swab, e=eye swab and (-) indicate negative results

* sheep number P.I=post inoculation

Kafrelsheikh Vet. Med. J. Vol. 9 No. 2 (2011) 


\subsection{Serological response of sheep following infection with} ZH501 or Smithburn strains: Optical density values of SPE revealed that the development of high titer of antibodies in serum samples of sheep in group I was demonstrated at $6^{\text {th }}$ and $7^{\text {th }}$ d.p.i with values ranged 0.085 to 0.099 and increased till the end of experiment reach 0.127 and 0.136 . In group $\Pi$ successful antibodies response started at $4^{\text {th }}$ d.p.i with values ranged from 0.087 to 0.089 and elevated to 0.166 and 0.175 at 21th d.p.i (the end of experiment) as demonstrated in table (3) and group $\Pi$ showed higher humoral immune response than group I figure (2).

Table (3): Evaluation of humorl response using SPE for sheep inoculated either with ZH501 or Smithburn strains of RVF virus.

\begin{tabular}{|c|c|c|c|c|c|c|c|c|c|}
\hline \multirow{2}{*}{$\begin{array}{c}\text { Days } \\
\text { P.I }\end{array}$} & \multicolumn{3}{|c|}{ Group I } & \multicolumn{3}{|c|}{ Group II } & \multicolumn{3}{|c|}{ Group III (control) } \\
\hline & ${ }^{*}$ Sh1 & Sh2 & Sh3 & Sh4 & Sh5 & Sh6 & Sh7 & Sh8 & Sh9 \\
\hline 0 & 0.078 & 0.07 & 0.065 & 0.075 & 0.069 & 0.075 & 0.064 & 0.063 & 0.065 \\
\hline 1 & 0.067 & 0.078 & 0.055 & 0.065 & 0.077 & 0.064 & 0.075 & 0.074 & 0.076 \\
\hline 2 & 0.074 & 0.078 & 0.071 & 0.064 & 0.075 & 0.061 & 0.064 & 0.062 & 0.066 \\
\hline 3 & 0.075 & 0.068 & 0.066 & 0.068 & 0.070 & 0.071 & 0.076 & 0.075 & 0.075 \\
\hline 4 & 0.076 & 0.069 & 0.064 & 0.089 & 0.087 & 0.088 & 0.071 & 0.070 & 0.071 \\
\hline 5 & 0.079 & 0.078 & 0.064 & 0.091 & 0.099 & 0.088 & 0.075 & 0.074 & 0.077 \\
\hline 6 & 0.072 & 0.085 & 0.077 & 0.094 & 0.097 & 0.090 & 0.071 & 0.071 & 0.070 \\
\hline 7 & 0.088 & 0.101 & 0.099 & 0.100 & 0.098 & 0.099 & 0.073 & 0.072 & 0.074 \\
\hline 8 & 0.099 & 0.105 & 0.108 & 0.104 & 0.100 & 0.099 & 0.056 & 0.060 & 0.055 \\
\hline 9 & 0.105 & 0.116 & 0.110 & 0.103 & 0.109 & 0.105 & 0.078 & 0.070 & 0.079 \\
\hline 10 & 0.101 & 0.109 & 0.119 & 0.103 & 0.121 & 0.100 & 0.074 & 0.068 & 0.077 \\
\hline 11 & 0.104 & 0.106 & 0.117 & 0.108 & 0.132 & 0.115 & 0.078 & 0.072 & 0.079 \\
\hline 12 & 0.114 & 0.112 & 0.102 & 0.107 & 0.130 & 0.113 & 0.072 & 0.068 & 0.070 \\
\hline 13 & 0.114 & 0.116 & 0.118 & 0.112 & 0.132 & 0.118 & 0.072 & 0.077 & 0.068 \\
\hline 14 & 0.121 & 0.117 & 0.110 & 0.120 & 0.129 & 0.129 & 0.077 & 0.075 & 0.076 \\
\hline 15 & 0.116 & 0.101 & 0.119 & 0.124 & 0.138 & 0.153 & 0.079 & 0.072 & 0.070 \\
\hline 16 & 0.107 & 0.112 & 0.112 & 0.140 & 0.137 & 0.145 & 0.065 & 0.060 & 0.064 \\
\hline 17 & 0.125 & 0.128 & 0.123 & 0.147 & 0.148 & 0.160 & 0.056 & 0.062 & 0.056 \\
\hline 18 & 0.120 & 0.118 & 0.121 & 0.145 & 0.155 & 0.160 & 0.066 & 0.070 & 0.066 \\
\hline 19 & 0.125 & 0.116 & 0.124 & 0.152 & 0.169 & 0.161 & 0.073 & 0.075 & 0.074 \\
\hline 20 & 0.128 & 0.13 & 0.129 & 0.148 & 0.161 & 0.171 & 0.079 & 0.079 & 0.072 \\
\hline 21 & 0.128 & 0.127 & 0.135 & 0.166 & 0.172 & 0.175 & 0.077 & 0.071 & 0.074 \\
\hline
\end{tabular}

Optical density values of SPE with positive results above 0.084 (Cut off value).

P.I (post. Inoculation). $\quad$ * sheep number

$\overline{\text { Kafrelsheikh Vet. Med. J. Vol. } 9 \text { No. } 2 \text { (2011) }}$ 

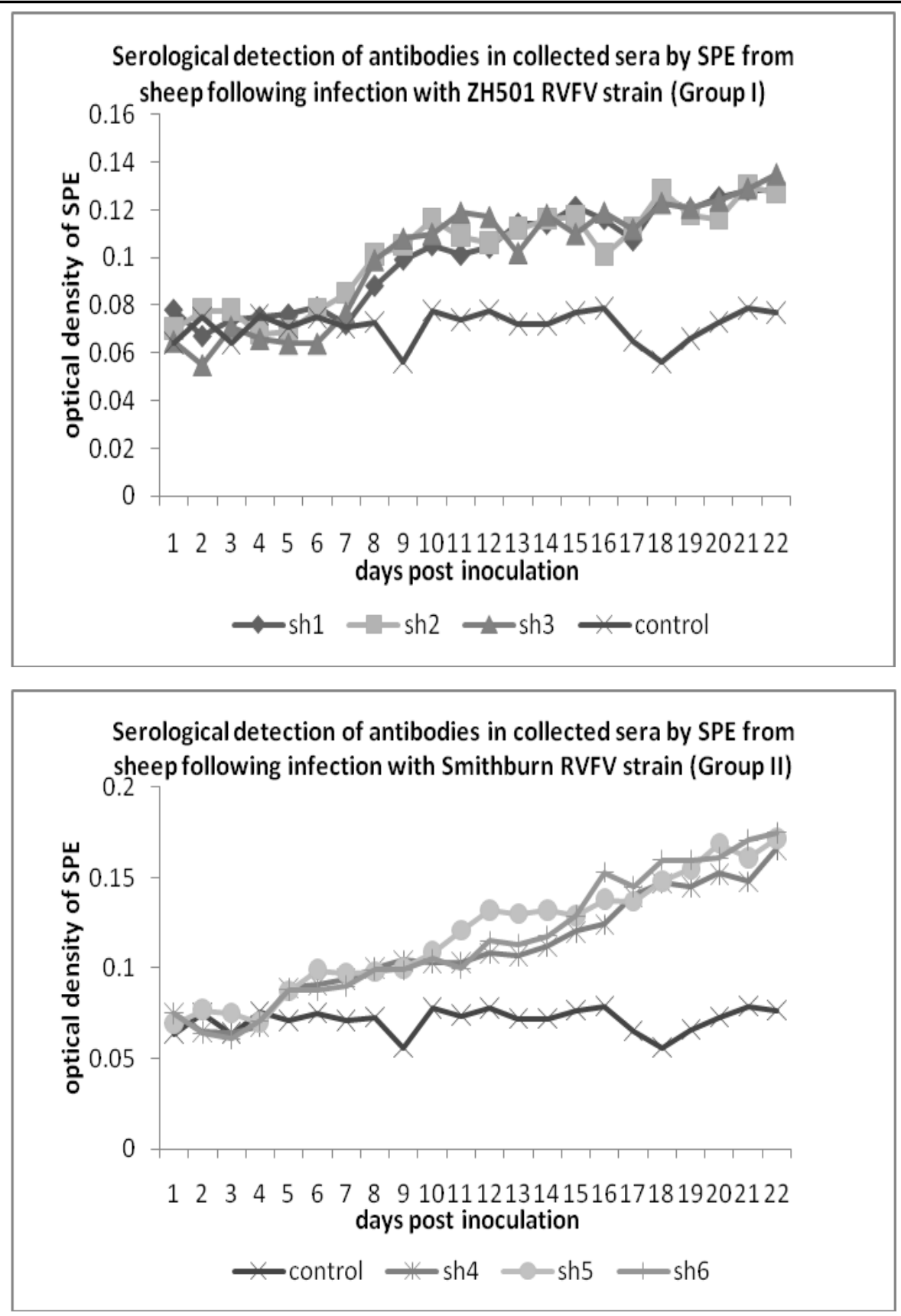

Figure (2): Higher humoral immune response of sheep in group $\Pi$ than that in group I 


\section{DISCUSSION}

Monitoring of rectal temperature for experimentally infected sheep revealed that the temperature started from the $1^{\text {st }}$ d.p.i and persisted until $5^{\text {th }}$ and $6^{\text {th }}$ d.p.i in group I and this agree with Ikram (1982) and Olaleye et al (1996) who reported the incubation period was 24hour and temperature return to normal level at $5^{\text {th }}$ d.p.i . In group II, increased body temperature was a normal behavior after inoculation of smithburn as an attenuated strain in which virus induce viraemia for a short period as obtained by Ibrahim (1996) and Bird et al (2009) following inoculation of living attenuated RVF vaccine.

In association with viraemia RVF virus persisted in plasma and buffy coat for $4^{\text {th }}$ and $5^{\text {th }}$ d.p.i and in serum for $10^{\text {th }}$ and $11^{\text {th }}$ d.p.i in group I our results comes in agreement with Gerdes (2004) and disagree with Fagabami et al (1975). who worked in the west African dwarf sheep that has natural resistance to RVF virus than other breed. In group II virus disappeared from serum at $5^{\text {th }}$ d.p.i and didn't excreted through faeces, nasal, ocular discharges, this finding attributed to short period of viraemia with attenuated strain as revealed by Pepin et al (2010).

In group1 the antibody response was demonstrated at $7^{\text {th }}$ d.p.i as mentioned by Ikram (1982) and Olaleye et al (1996) and the clearance of virus on the $10^{\text {th }}$ and $11^{\text {th }}$ d.p.i may be due to early development of antibody which neutralizes the virus particle. While in group II the antibody response began to appear at $4^{\text {th }}$ d.p.i as observed by Ibrahim, (1996) and Pepin et al (2010). 
For RVF virus protective immunity is not just the result of stimulation of neutralizing antibody but involve a response to other virus epitopes as reported by Kathryn et al (1991), so higher amount of antibodies detected by solid phase ELISA in group $\Pi$ than group I was indicative for the use of Smithburn strain as attenuated vaccine and a seed for production of inactivated vaccine against RVF virus.

\section{REFERENCES}

- Bird, B.H., Ksiazek, T.G., Nichol, S.T., and Maclachlan N.J. (2009): Rift Valley fever virus. J. Am. Vet. Med. Assoc. 234: 883-893.

- Diallo, M., Nabeth, P., Ba, K., Sall, A., Ba, Y.,Mondo,M., Girault, L., Abdalahi,M. and Mathiot, C. (2005): Mosquito vectors of the 1998-1999 outbreak of Rift Valley Fever and other arboviruses (Bagaza, anar,Wesselsbron and West Nile) in Mauritania and Senegal. Med. Vet. Entomol. 19, 119-126.

- Fagbami, A.H., Tomori O., Fabiyi A., Isoun T.T. (1975): Experimental Rift Valley fever in West African Dwarf sheep, Res. Vet. Sci. 18:334-335.

- Flick, R., and Bouloy, M. ( 2005): Rift Valley fever virus. Curr. Mol. Med. 5, 827-834

- Florence, G. Burleson; Thomas, M. Chambers and Danny, L. Wiedbrauk (1992): Virology A Laboratory Manual. Academic press, New York.

- Gerdes G.H. (2004): Rift Valley fever, Rev. Sci. Tech.Off. Int. Epizoot. 23:613-623. 
- Gubler, D.J. (2002): The global emergence/resurgence of arboviral diseases as public health problems. Arch. Med. Res. 33,330-342

- Ibrahim, A. M. (1996): Comparative Studies on different Rift Valley Fever attenuated vaccine.M. Vet. Sic Thesis, Infectious Diseases. Fac. Vet. Med., Zagazig University, Banha Branch, Egypt..

- Ikram, A. A. (1982): Studies on Rift Valley Fever virus. Ph. D. Thesis (Microbiology), Fac. Vet. Med., Cairo University, Egypt.

- Kathryn, A.; Hubbard, B.S.C.; Arthur, b. and John, A. (1991): Ability of a mutagenized virus variant to protect young lambs from RVF. Am. J. Vet. Res., 52 (1): 50-55.

- Macpherson,J.A. and Stocker, N.G. (1962): Polyoma Transformation of hamster cell clones an investigation of hamster cell clones of genetic factors affecting all competence. Virology, 16: 147-151.

- Olaleye O.D., Tomori O., Fajimi J.L., Schmitz H. (1996): Experimental infection of three Nigerian breeds of sheep with the Zinga strain of the Rift Valley fever virus, Rev. Elev. Med. Vet. Pays Trop. 49:6-16.

- Pepin, M.; Bouloy, M.; Bird, B. H.; Kemp, A.; and Paweska, J. (2010): Rift Valley fever virus (Bunyaviridae: Phlebovirus): an update on pathogenesis, molecular epidemiology, vectors, diagnostics and prevention. Vet. Res. 41:61.

- Snoy, P.J. (2010): Establishing efficacy of human products using animals: the US Food and Drug Administration's "Animal Rule". Vet. Pathol. 47, 774-778.

- Voller, A., Bidwell, D.E. and Annbarlett, M. (1976): Enzyme immuno assays in diagnostic medicine, theory and practice. Bull. World. Health, organ, 63: 55-65. 
العدوى التجريبية للاغنام بعترات من فيروس حمى الو ادى المتصدع.

$$
\begin{aligned}
& \text { إيهاب مصطفى النحاس } \\
& \text { قسم الفيرولوجيا - كلية الطب البيطرى بمثنهر - جامعة بنها -مصر }
\end{aligned}
$$

تم تقسيم عدد ثشعة أغنام بلدي عمرها خمسة أثنهر إلى 3 مجموعات. حقتت المجموعة الأولى بفيروس حمى الوادي المنصدع عترة ZH501 والمجموعة الثنانية بفيروس حمى الوادي المنصدع عترة سميث برن وتركت المجموعة الثالثة دون حقن كمجوعة ضابطة. نم تسجيل درجة الحرارة ومحاولة العزل والتعرف على الفيروسات المحقونة إلى جانب متابعة الأجسام المناعية المضادة باستخدام اختبار الاليزا غير المباشر • بالنسبة للمجموعة الأولى استمرت الحرارة لمدة 5أو6 أيام , وأمكن عزل الفيروس من العين في اليوم الثالث والسابع من الحقن ومن الأنف في اليوم الثالث ومن الثرج في اليوم الثالث والتاسع من الحقن بينما نوقف العزل من البلازما وطبقة الخلايا الليمفاوية عند اليوم الخامس والسيرم حتى اليوم الحادي عشر , وظهرت الأجسام المناعية في اليوم السادس والسابع وأخذت في الزيادة حتى نهاية التجربة. أما المجموعة الثانية فقد ارتفعت الحرارة ارتفاعا طفيفا عند اليوم الثالث أو الرابع من الحقن ولم يتم العزل من العين أو الأنف أو الثرج ,ولكن أمكن تتبع الفيروس في الدم إلى اليوم الثالث والرابع من الحقن, وظهرت الأجسام المناعية من اليوم الرابع وأخذت في التزايد بمعلات اكبر من مثنالتها فى المجموعة الأولى. أما المجموعة الضابطة لم تظهر بها أي تغيرات وكذلك كانت خالية من الفيروس وأجسامه المناعية. ومن ثم فان عترة سميث برن يمكن استخدامها كالقاح مستضعف أو كبذرة لإنتاج لقاح مثبط حيث أنها أكثر استحثاثا للجهاز المناعي عن العترة ZH501. 